\title{
Challenges of Transformation: Innovation, Re-bundling and Traditional Manufacturing in Canada's Technology Triangle
}

\author{
Harald Bathelt, Andrew K. Munro \& Ben Spigel
}

\author{
Version Post-print/accepted manuscript \\ Citation Bathelt, H., Munro, A. K., \& Spigel, B. (2013). Challenges of \\ (published version) transformation: Innovation, re-bundling and traditional manufacturing \\ in Canada's Technology Triangle. Regional Studies, 47(7), 1111-1130. \\ Copyright / License \\ Publisher's Statement This is an Accepted Manuscript of an article published by Taylor \& \\ Francis in Regional Studies on Oct 2011, available online: \\ http://www.tandfonline.com/10.1080/00343404.2011.602058
}

Always cite the published version, so the author(s) will receive recognition through services that track citation counts, e.g. Scopus. If you need to cite the page number of the TSpace version (original manuscript or accepted manuscript) because you cannot access the published version, then cite the TSpace version in addition to the published version using the permanent URI (handle) found on the record page. 


\title{
Challenges of Transformation: Innovation, Re-bundling and Traditional Manufacturing in Canada's Technology Triangle
}

\author{
Harald Bathelt \\ University of Toronto, Department of Political Science and Department of Geography \& \\ Program in Planning, Sidney Smith Hall, 100 St. George Street, Toronto ON M5S 3G3, \\ Canada, \\ E-mail: harald.bathelt@utoronto.ca, URL: http://www.harald-bathelt.com
}

Andrew K. Munro

University of Toronto, Institute for the History and Philosophy of Science and Technology, Victoria College, 91 Charles Street West, Toronto ON M5S 1K7, Canada,

E-mail: andrew.munro@utoronto.ca

and

Ben Spigel

University of Toronto, Department of Geography \& Program in Planning, Sidney Smith Hall, 100 St. George Street, Toronto ON M5S 3G3, Canada, E-mail: ben.spigel@utoronto.ca

Paper

accepted for publication in

Regional Studies 


\section{Challenges of Transformation: Innovation, Re-bundling and Traditional Manufacturing in Canada's Technology Triangle}

English Abstract (ca. 100 words): This paper develops a perspective of regional rebundling in overcoming economic crises. It does this by focusing on the effects of the recent global financial crisis on traditional manufacturing. We analyze the structure of innovation processes and their development over time in Canada's Technology Triangle - a region known for university-related spin-off processes and successful modernization. What is less well-known is that this region has been strongly influenced by traditional manufacturing industries. We show that these industries have been well prepared to deal with the effects of the crisis due to ongoing innovation and diversification stimulated by prior economic crises.

Keywords. Canada's Technology Triangle; manufacturing sector; global financial crisis; re-bundling; innovation practices/strategies

JEL Classifications. L16; L62; O31; R11 


\section{Herausforderungen der Transformation: Innovationsprozesse, Re- bundling und traditionelle Industrien in Canada's Technology Triangle}

German Abstract (ca. 100 words). Der Beitrag entwickelt eine Perspektive regionaler Re-bundling-(Neubündelungs-)Prozesse zur Überwindung ökonomischer Krisen. Der Fokus der Studie liegt bei den Auswirkungen der globalen Finanzkrise Ende der 2000er Jahre auf traditionelle Industrien. Untersucht werden die Struktur von Innovationsprozessen und ihr Wandel am Beispiel von Canada's Technology Triangle - einer Region, die durch universitätsbezogene Spin-offs und ökonomische Modernisierungsprozesse bekannt geworden ist. Weniger bekannt ist dagegen, dass die Region ebenso durch traditionelle Industriesektoren geprägt ist. Die Ergebnisse der durchgeführten Unternehmensbefragungen zeigen, dass die betreffenden Industrien überraschend gut auf die Wirtschaftskrise vorbereitet waren und darauf reagieren konnten. Dies hing mit andauernden Innovationsprozessen und Diversifizierungsbemühungen zusammen, die durch vorhergehende Krisen ausgelöst worden waren.

Keywords. Canada's Technology Triangle; traditionelle Industrien; globale Finanzkrise; re-bundling; Innovationspraktiken/-strategien

JEL Classifications. L16; L62; O31; R11 


\section{Introduction}

To date, limited information is available about the consequences of the recent global financial crisis on traditional manufacturing industries, even though these industries, especially automobile-related branches, were hit hardest. This study investigates the effects of this crisis on regional innovation practices and structures in a case study of "Canada's Technology Triangle" (CTT) - a region about $100 \mathrm{~km}$ west of Toronto - which consists of the Kitchener and Guelph metropolitan areas. ${ }^{1}$ This region is regarded as one of Canada's "model economies," a claim based primarily on the region's success in the transformation from a traditional manufacturing economy to one that increasingly includes new information technologies.

Between 2001 and 2006, the Kitchener census metropolitan area (CMA) and the Guelph census agglomeration (CA) experienced an increase in population and jobs significantly higher than the national and provincial growth rates and similar to those in the Toronto CMA (Bathelt et al., 2010). The unemployment rates were among the lowest in any Canadian metropolitan area. In 2006, the unemployment rate in the Kitchener CMA and the Guelph CA was 5.6\% and 5.1\%, respectively, compared to $6.4 \%$ in Toronto and $6.1 \%$ in Canada (Statistics Canada, 2006). This supports the view that this region benefited from university spin-offs and related transformation processes. Numerous information technology firms, such as Open Text and Research in Motion - the maker of the now famous Blackberry device - have been successfully spun off by researchers and students at the University of Waterloo, establishing a growing high-technology sector in the region (Bathelt and Hecht, 1990; Bramwell and Wolfe, 2008), with supposedly high growth potential in "creative economy" sectors (BMO Capital Markets, 2008; Florida and Martin, 2009).

In the media hype around CTT's supposedly “post-industrial” future (Perry, 2009), it is often forgotten that the region has a strong manufacturing tradition (English and McLaughlin, 
1983; Vinodrai, 2011) that remains important for the region today (Holmes et al., 2005;

Rutherford and Holmes, 2008). Both academic and policy research on innovation tends to focus on its "elite" forms in high-technology industries and ignores the often informal innovation activities that happen in traditional industries (Rutherford and Holmes, 2007). In 2008, approximately 44,100 of 76,700 manufacturing employees (57\%) and 1,048 of 2,164 establishments (48\%) in the region fell within traditional manufacturing segments in the metalfabricating/processing, plastics and rubber, electrical equipment, and automobile supplier industries (Table 1). In the Kitchener CMA, the manufacturing sector had a share of $20.3 \%$ of the total labor force in 2007, nearly twice the Canadian average (Figure 1). As such, this sector's contribution, despite a precipitous decline in the past decade, cannot be neglected in the regional success story.

[Insert Table 1 and Figure 1 about here]

The onset of the global financial crisis of 2008-2009 was unique in both its speed and severity, making it reasonable to expect that it would have a significant impact on the region's economy given its dependence on traditional manufacturing. What started as a crisis and collapse in the US housing market quickly spread globally through complex webs of financial derivatives, causing panic in international credit markets (Engelen and Faulconbridge, 2009). The automotive sector - already reeling from drops in sales due to high gas prices at that time - experienced a dramatic decline in sales as consumer credit was all but cut-off. Like other economic downturns, this led to a crisis of demand as downstream firms cut down on their manufacturing inputs, leading to a ripple-effect through the global production system.

The Kitchener and Guelph metropolitan areas were strongly hit by the crisis as indicated by shifts in unemployment figures. In March 2009, the unemployment rate in the Kitchener CMA increased to $9.6 \%$, exceeding the respective figures of the Toronto CMA (8.8\%) and 
Canada (7.6 \%). Compared to a year earlier, unemployment had almost doubled. The region lost over 10,000 manufacturing jobs since early 2007 , representing more than a $17 \%$ loss in this sector (Statistics Canada, 2009). The CEO of Guelph-based Linamar, Linda Hasenfratz, warned at the annual Canadian Manufacturing Trade Show in Toronto: "There is a worry that we're going to see another wave of bankruptcies" (Van Alphen, 2009). This is, however, not what happened as the automobile supplier sector began to recover and new manufacturing jobs were created pushing the unemployment rate down (Van Alphen, 2010; Statistics Canada, 2010b; 2010c).

This study was designed as one of the first empirical studies in economic geography that systematically analyzes the relationship between regional innovation practices and the global financial crisis. Accordingly, the current study has three goals: First, it aims to investigate the innovation practices and strategies employed by traditional manufacturing firms during the crisis. The second goal is to explore in which way firms in these industries have been affected by the recent crisis. The third goal investigates which responses and strategies firms have developed to cope with the crisis effects. These aspects are analyzed in the context of a conception of regional ruptures and re-bundling.

Based on these goals, the paper is structured as follows: In Section 2, the conception of regional ruptures and re-bundling is discussed that allows us to investigate the effects of economic crises on regional development trajectories. Section 3 discusses the methodology used and the empirical data analyzed. Section 4 identifies and characterizes the current structure of innovation linkages and types of innovation practices observed in the traditional manufacturing sector of CTT. Section 5 investigates the effects of and responses to the global financial crisis emphasizing the role of ongoing innovation and adjustments. Finally, Section 6 draws conclusions. 


\section{Conceptual Background: Re-bundling of Knowledge and Other Resources}

This section develops a conceptualization of regional economic development paths that led our analysis of the innovation practices and dynamics of CTT's traditional manufacturing economy. We are particularly interested in a framework that addresses the role of major economic crises and their impacts on regional development. Much of the literature in economic geography on related issues (e.g. Rigby and Essletzbichler, 1997; Boschma and Lamboy, 1999; Grabher, 1993; Hassink, 2005; Martin and Sunley, 2006) employs an explicitly evolutionary conception of the economy (Nelson and Winter, 1982; Dosi, 1988).

While acknowledging discontinuous technological change, these studies often focus on technological continuity and lock-in. Although such a focus helps to understand how development trajectories are formed, it is less helpful in periods of crisis characterized by unexpected ruptures and discontinuities. A lock-in perspective (Martin, 2010) also appears to emphasize past structures rather than looking forward on processes of restructuring or rebundling. Similarly, perspectives that emphasize equilibrium tendencies, such as some of the resilience approaches (Christopherson et al., 2010), seem ill-equipped to deal with periods of fundamental ruptures. This paper assumes, instead, that economies are in a state of constant change and ongoing power struggles that might lead to temporary fixes, but not to a static equilibrium (Taylor, 2000; Chapman et al., 2004; Bathelt, 2009). Overall, evolutionary accounts tend to over-emphasize continuous adaptation while neglecting political economy contexts and ruptures (see, also, MacKinnon et al., 2009).

While recent work combining evolutionary economic geography and resiliency have explicitly addressed the role of economic and technological discontinuities in regional economic development (Simmie and Martin, 2010), the literature as a whole is still focused on the gradual 
evolution of regional economies with little discussion about how regions adapt to sudden crises. Regional diversification in this approach frequently occurs through a branching process, whereby new products and services are based on existing competencies and skills (Neffke et al., 2009). When firms diversify their product lines, their new endeavors emerge from the firm's own previous experience and competencies, and from locally available knowledge and resources (Boschma and Frenken, 2011). While this process allows firms to move up a supply chain and improve their profitability, it also makes them vulnerable to sudden declines in demand. Regions with a diverse set of industries and exports, however, may enable local firms to diversify the markets and industries they serve by tapping into the varied set of local resources and competencies available locally (Frenken et al., 2007).

The branching-out approach has much in common with the re-bundling perspective developed in this paper, though work on branching-out primarily focuses on ex-post analyses of regional developments based on large data sets. It also prioritizes a view of regional continuity along bundles of related activities and competencies and, as such, may sometimes overlook largely unconnected developments after crisis situations. ${ }^{2}$ In contrast, we are interested to develop a conceptualization that includes both related and unrelated developments and allows us to study regional development during crisis periods using a qualitative method of inquiry to explore the nature of and rationales behind economic decision-making. We are particularly interested in investigating how such processes at the firm level translate into regional trends and developments in aggregate form.

Storper and Walker's (1989) model of regional industrial development makes an important step in addressing technological discontinuities by suggesting that regional development is characterized by periods of relatively drastic change and periods of more incremental, successive changes in the spatial organization of industries. In this model, newly 
developing industries challenge existing spatial industry patterns and institutional settings, causing what Storper and Walker (1989) refer to as "shifting centers" (Scott, 1988).

We use this model and Penrose's (1959) analysis of the growth of the firm as a starting point for our conceptualization. Penrose's (1959) work - which provides an important basis for the resource-based view of the firm (Wernerfelt, 1984) - sees firms as bundles of resources and resources as bundles of possible services. This suggests that it is not possible to differentiate between resources and their respective services, because resources can serve a variety of purposes, depending on the context in which they are employed. According to Penrose (1997, 31): "Strictly speaking, it is never resources themselves that are 'inputs' in the production process, but only the services that the resources can render." This provides the basis for a relational understanding of resources or, in a broader sense, capital. In this way, regional ruptures or crises provide the basis for de-contextualizing and subsequently re-contextualizing different forms of capital and their specific uses. Re-bundling can be understood as both a process through which new resources are integrated into the regional production process and how existing resources, such as knowledge, are used in different ways to serve a different purpose (Bathelt and Boggs, 2003; Bathelt, 2009). In other words, re-bundling is a process that readjusts existing and new, internal and external resources to the needs of new socio-political and economic settings. We use the term here with respect to regional contexts of crisis and restructuring that start at the firm level and build up in aggregate and collective ways to the regional level.

Political and economic crises strain a regional economy's social cohesion. They disrupt existing transactional networks, releasing resources for alternative uses. Suppliers and service firms, previously focusing on the needs of the dominant sector, are now open to new ventures and technologies developed in other sectors and/or other regions. Crises lead to two kinds of adjustments or shifts: (i) geographical shifts, as assets leave the region; and (ii) 
sectoral/technological shifts, as assets are re-deployed to the region's other sectors and technologies. Both forms clearly impact the nature of regional innovation. While geographical shifts may lead to cumulative shrinking processes (Myrdal, 1957), sectoral/technological shifts may cause innovations and capabilities developed in one sector to filter into another. Drawing on North American experiences, Feldman and Francis (2006) argue that in periods of crisis and discontinuity, entrepreneurial potential can be mobilized, resulting in the establishment of new firms that may drive regional development later on.

Regions begin to recover from a crisis when agents re-bundle the resources at hand (i.e. financial, physical, human and social capital) for a new round of accumulation. Interactive learning and innovation processes may enable the region's actors to re-bundle technological trajectories if they can mobilize or redirect resources and agents towards collective action (Bathelt and Boggs, 2003). Not every new bundle of technologies and related economic activities necessarily has a significant positive impact on a region's development. In order to shape the development path and help overcome the regional crisis, a new ensemble of specialized resources and competencies must develop. This new bundle must be anchored to the local economy by non-ubiquitous resources found within a specialized social division of labor. It also must have a certain minimum size and must develop institutions to reproduce itself - to be able to achieve broader adaptability in the sense of Grabher and Stark (1997). From a regional perspective, this suggests that even though actions in response to a crisis are largely carried out by firms based on their own unique situation, these actions (such as layoffs, exiting markets or innovating) contribute to the larger regional pool of resources which all firms might draw upon through social and spatial divisions of labor within and across value chains.

The concept of re-bundling does not imply that regional crises are overcome through regional assets alone. In fact, re-bundling processes are often initiated or supported by external 
agents and capital, which may be more or less related to prior developments. For instance, integration into global production networks and the resulting access to outside resources and markets are often essential to regional competitiveness (Scott, 1998; Amin, 2004; Owen-Smith and Powell, 2004). In order to anchor these initiatives within a region and trigger regional development, local actors, of course, must also be mobilized - a process that is easier to achieve if taking place in related sectors (Boschma and Frenken, 2011). Therefore, the re-bundling perspective focuses on those agents and assets which can be mobilized to anchor a particular technological trajectory within a region.

Figure 2 clarifies the relationship between regional economic structure, crisis and the rebundling of resources in the context of regional development paths. The sequence shown in this diagram begins at time $t$, when the regional development path is shaped by an industry structure that evolved in the past characterized by a traditional mixture of intra-regional and extra-regional innovation linkages. In the next stage, time $t+1$, a political, economic or technological crisis has shattered the regional industry structure. Whether this rupture leads to a deeper long-term crisis in period $t+2$ (cases a and $\mathrm{b}$ ), or triggers re-bundling processes that revive existing and develop new structures (cases $\mathrm{c}$ and d), depends on the nature of re-bundling and restructuring processes that take place at the firm level and the availability and mobilization of additional resources. The following brief discussion of re-bundling processes focuses on four ideal-type scenarios at period $t+2$. We particularly focus on different recombinations of resources and the role of innovation in structuring re-bundling (Chapman et al., 2004; Martin, 2010):

[Insert Figure 2 about here]

Case a: No Re-bundling. This case is characterized by massive plant closures and lay-offs leading to long-term decline. Resources remain unused as the unemployment rates sharply increase and industrial spaces are left empty. Active re-bundling strategies are not applied and, 
consequently, new economic linkages in production and innovation are not formed, leading to "regional paralysis".

Case b: Un-bundling. This scenario leads to a relocation of firms to other regions and nations, with consequences similar to case a. In aggregate form, persistent regional decline may result, while the regional resource base shrinks and mobile labor leaves the region to find new employment opportunities. Existing innovative linkages are minimized and new linkages pass over the region, leaving an isolated regional economy with little innovation.

Case c: Ongoing Re-bundling. The next scenario describes a situation where agents are not unprepared for crisis situations, as they engage in continuous innovation and adaptations of existing structures and linkages. The crisis still impacts the regional resource base, but firms are able to build on prior innovation to minimize regional effects. The likely trajectory is based on cumulative development patterns and leads to a slow but steady recovery. This development relies on the initiatives of regional agents.

Case d: Radical Re-bundling. The last scenario is the most optimistic in terms of the mobilization of new external resources and the engagement of new agents from other regions and countries in the restructuring process. This can lead to a more fundamental, discontinuous shift in the regional industry base and innovation structure, especially in relation to cross-regional and international value chains.

While Chapman et al. (2004) focus on two distinct paths of re-orientation (i.e. renewal and adjustment), our stylized re-bundling scenarios draw a more diverse action-space and extend this classification by explicitly distinguishing between internal and external resources. Similar to Chapman et al. (2004), we view diversification as an important strategy in overcoming crises. In the context of innovation, practices may be incremental or more radical in nature. In the end, 
aggregate and collective re-bundling activities - the act of re-adjusting longstanding patterns of capital investment, accumulation and labor relations - help make regional economies more "resilient" to large-scale economic change. ${ }^{3}$ Resilient regional economies, especially cases (c) and (d), may still experience decline and reinvestment in times of crisis, but retain the internal capacity to change their industrial structure to take advantage of new markets and industries. While entrepreneurship is a critical factor in developing resilient regional economies (Malecki, 2009), attention needs to be paid to the ability of existing firms to re-bundle existing resources and competencies during times of economic upheaval.

Based on this conceptualization, we next discuss the methodology applied and empirical study conducted.

\section{Methodology and Data Basis}

While this study originally intended to investigate the innovation practices in CTT's traditional manufacturing sector and local and non-local innovation linkages with suppliers, customers and other partners, our goal shifted with the global financial crisis. We decided to use a qualitative framework to explore the nature and dynamics of innovative practices chosen in response to the crisis, and understand the strategies behind firms' actions and decisions (Eisenhardt, 1989). Despite this explorative focus, we organized our survey as a larger random sample (while adding a limited number of regional key firms). Through this, we intended to represent a substantial part of the region's traditional manufacturing sector and make more general claims about some of the region's dominant innovation practices and responses to the crisis.

Between November 2008 and May 2009, we conducted 40 in-depth, semi-structured interviews with the owners or managers of industrial firms. These interviews, which lasted from 30 minutes to over one and a half hours, aimed to investigate what role innovation and R\&D 
played in the creation and maintenance of competitive advantage. First, questions were raised regarding the start-up processes, location decisions and the region's characteristics. Second, particular attention was paid to the innovative linkages firms had with local and non-local customers, suppliers and competitors. Other topics touched on the firms' affiliations with industry and trade groups, their attendance at trade fairs, use of Internet forums to generate innovative ideas, as well as their links to universities or other research laboratories. Third, questions were asked to inquire about the nature and effect of the global financial crisis on firm performance and innovation.

Although our study region is primarily known for its high-technology start-up culture and university spin-offs, it is also a major center of manufacturing industries in Canada (Figure 1). Its proximity to Toronto, the steel mills of Hamilton, the automobile industry in Southern Ontario, as well as major US markets contribute to its manufacturing strength. The region and its immediate surroundings feature two major automobile plants (Toyota and Honda) and several major auto parts manufacturers along with other major industrial firms. These are both locally owned as well as subsidiaries of global corporations.

To select a study population, we first examined the industrial makeup of the CambridgeGuelph-Kitchener-Waterloo region. The focus was on sectors with higher than normal concentrations in the region, compared to the Canadian average. Table 1 shows the location quotients (LQs) related to the number of firms and employees in all 21 manufacturing sectors of the North American Industry Classification System (NAICS) for 2008. From this, we selected 5 traditional manufacturing sectors with above-average concentrations of firms and employees. These sectors were plastics and rubber manufacturing (NAICS code 326), fabricated metal products manufacturing (332), machinery manufacturing (333), electrical equipment manufacturing (335) and transportation equipment manufacturing (336). As shown in Table 1, 
these traditional industries are quite important in the region, with about 44,000 employees and over 1,000 firms (Statistics Canada, 2008). These sectors are not normally considered to be particularly innovative. In fact, a lack of $R \& D$ and innovation has been blamed for the gradual decline in the region's traditional manufacturing sectors (Bagchi-Sen, 2001).

Our study population was created based on a business directory provided by CTT Incorporated, the local economic development agency. Within the study region, this database listed 642 firms in the 5 sectors selected. From this list, a stratified random sample (with a small number of pre-selected key firms) was taken, and 310 firms were approached. After several rounds of contacts, 40 firms were successfully interviewed, producing a response rate of $12.9 \%$. While this seems low, this was to be expected because the field work was conducted during the global financial crisis in 2008 and 2009.

We began contacting and interviewing firms for this study in November 2008. This was within days of the major automobile manufacturers announcing that their last-month sales had declined by $25-40 \%$ from the previous year (Bunkley, 2008), and less than two months after the collapse of Lehman Brothers. This was clearly reflected in the reactions we experienced: One interview, for instance, booked with a small parts manufacturer who produced parts for General Motors was canceled by the owner one day after initial plans for an auto bailout were derailed by the U.S Treasury, saying that he was "struggling to survive."

As Schoenberger (1991) notes, interviews with executives and managers are laden with complex power dynamics. Even in the best of times, it can be difficult for academics to persuade executives to spend an hour or more on an interview. This is doubly true during times of crisis. Executives of firms that were doing better in the crisis likely had more time - and were more willing - to talk to us than those in firms struggling to remain solvent (Welch et al., 2002). In the midst of the largest economic crisis in the post-World War II era, managers at firms often felt 
they had nothing to contribute to a study on innovation and would decline to be interviewed. Other potential interviewees were not reached because their firms' operations had been terminated or were in the process of being downsized or shut down. ${ }^{5}$

While these are experiences that we share with many large- $n$ surveys, we still believe that our study provides substantial insight into innovation dynamics and re-bundling processes in a period of crisis. This is because some interviews were done at the onset of the crisis, but others took place when the crisis was well on the way and winding down. We also asked firms to relate their practices and reactions to those of others and thus gained wider insights into regional dynamics. For the same reason, further explorative interviews with economic development officers and industry representatives helped us triangulate the firm information.

Tables 2, 3 and 4 break down the interviewed firms by location, industry group and employment size. While there was a slight over-sampling of firms from Guelph and an undersampling of firms from Cambridge, this does not represent a systematic bias to our sample (Table 2). In terms of sectoral composition, we found no significant difference between the overall firm population and our sample (Table 3). Lastly, because of our interest in interviewing larger firms, there is a moderate but insignificant bias towards larger firms (Table 4). Overall, structural data and the results of triangulation do not suggest that there is a notable bias in our sample of firms that could lead to problematic results. Given all the uncertainties of conducting empirical research during periods of crisis, we feel confident that our data represents key trends and characteristics in our study region.

[Insert Tables 2, 3 and 4 about here]

In addition, there are many signs that the region has overcome the worst stage of the financial crisis and that ongoing innovation processes, as discussed below, have contributed to regional reinvigoration. Between August 2009 and August 2010, for instance, about 8,500 new 
manufacturing jobs were created in the Kitchener MSA (Statistics Canada, 2010b) and the unemployment rate, which had surpassed the national average, decreased from $9.9 \%$ to $7.0 \%$ (Statistics Canada, 2010c). In August 2010, the unemployment rate was below that of the Toronto MSA (9.1\%) and Canada overall (8.0\%). A study of the Ontario Manufacturing Council $(2010,1)$ concluded that “... economic conditions in Ontario’s manufacturing sector have stabilized, and have now begun to recover", particularly related to new technologies and innovation in traditional manufacturing sectors.

\section{Structure of Innovation Linkages in the Kitchener and Guelph Metropolitan Regions}

\subsection{Structure of Sample Firms}

The firms interviewed range in size from two-person machine shops to fully-integrated factories of multinational firms. We divided the firms into four categories based on their position in the industry's value chain (Table 5). The fabrication firms (21 out of 40 in our sample) are primarily machine shops that do contract work of short-to-medium runs of products using CNC machine tool systems. They tend to service firms beyond just the CTT region, with a customerbase located throughout Southern Ontario. A second group of firms ( 5 out of 40) provide some form of product preparation service, such as electro-plating, finishing, welding or painting. These firms service primarily the Southern Ontario region, but some of the firms have key customers located in the US. A third category of assembler or system integration firms ( 2 out of 40 ) have regional customers that are located primarily in CTT and in the Greater Toronto Area (GTA). These firms take standardized products or commodities available from multiple third-party sources or online catalogs, which they assemble into a product according to customer designs. The fourth group of firms consists of OEMs - original equipment manufacturers (12 out of 40 
firms). These OEMs include headquarters of national and international firms, along with branch plants of multinational corporations. Among these are also a handful of single-facility manufacturers that sell nationally and internationally.

[Insert Table 5 about here]

\subsection{Heterogeneous Innovation Practices}

We asked the firms a series of questions to explore the nature of innovations introduced in the last two years (Table 6). A total of 7 firms (17\%) indicated that they had not added any new processes or products over the last two years. These non-innovators were fabrication or coating and heat treating firms, working with mature processes or in niche markets with little competition. Two of the firms interviewed, however, were floundering and, according to their owners, could not innovate because they were trying to survive. They operated in market segments with high-volume products and low profit margins. These two firms were seemingly unable to afford the costs of innovation because of fierce global competition and cost pressure. Their problems long pre-dated the global economic crisis. They were limited in their capacity to produce new linkages in the region, limiting their ability to assist in regional re-bundling efforts. But the remaining 5 non-innovative firms provided important services for other manufacturing firms in the region.

\section{[Insert Table 6 about here]}

The majority of the firms (33 firms or $83 \%$ ) added new products or processes to their operations over the past two years prior to our interviews. This was much more than what we expected to find in a manufacturing sector that is often viewed as less innovative. This indicates that many firms in this traditional industry segment actively contributed to regional re-bundling activities. Of these firms, 16 said they added new products, while 17 engaged in process innovation (Table 6). Of the firms that provided new products, the majority were OEMs. These 
firms were fully involved in the design and manufacture of their products. Although outsourcing parts of their production, they kept control over the final assembly, marketing and distribution of their products.

In line with Fuchs and Kempermann's (2010) and Hahn's (2010) research of German mechanical engineering and automotive industries, we found that many firms in CTT applied active innovation strategies. Overall, we were able identify 5 distinct, partly overlapping types of innovative practices that generally corresponded with the role firms had in the design of products. In aggregate form, this enables us to draw conclusions about regional re-bundling processes:

(a) No Design Involvement. Of the 40 firms interviewed, 15 had no involvement in the design of the products and little-to-no knowledge about the end use of the products they work on (Table 6). They communicated in a very limited way with their customers to solve problems related to the manufacturability of products. This type of firms consisted of fabrication shops (10 firms) and manufacturing process service firms ( 5 firms). The firms operated according to blueprint or process specifications, worked mainly with mature processes and competed on price. Their innovation processes were primarily related to improvements in product-flow and the minimization of waste material.

Only a few firms engaged in some minimal, primarily process-related, innovation through their value chains. This was exemplified by the comments of the owner and president of a friction-welding firm that sent samples of its products to a metallurgical laboratory in the region: "We have had a relationship with them for so long that they have developed the skills at that facility [to examine our product for fatiguing], and we recently discovered that other [friction welding] firms were sending their material to this lab [as well], because they knew what they were looking at" (Interview I201). Friction welding was an uncommon process, and the firm was supposedly one of a handful in North America that provided that service on a contract job 
basis. The laboratory was thus able to offer a unique service to friction welding firms throughout North America. Although these firms are unlikely the drivers of regional re-bundling processes on their own, the example above demonstrates that even firms with limited innovative capacity can provide novel capabilities to a region and create cross-regional linkages.

(b) Manufacturing According to Customer Specification. In addition to the 15 firm that were not involved in the design of products, another 8 firms also worked according to specifications provided by customers but, when encountering problems in manufacturing, were able to provide some feedback to their customers and suggest changes to the design ${ }^{6}$. This is best exemplified by the metal fabrication shops in our sample. Most of these firms focused on a few long-term clients for the bulk of their business and supplemented this with short-run contract projects from other firms. ${ }^{7}$ They typically received the blueprint, determined the best way to fabricate the parts internally, executed the fabrication of the parts and components accordingly and shipped the finished parts back to the customer or other firms for additional treatment or assembly. As one interviewee put it: "The customer just wants the end product to their specs. They don't need to know how we manufacture it" (Interview I221). These firms were expected to produce a product reliably according to specifications, with quick turnaround times and minimal delays. When problems were encountered, they were often the result of the customers' design not being optimal for manufacturing.

Many of the firms had limited resources and were not able to research new technologies. Even some of the larger fabrication firms were challenged to find resources for innovation, as lean production practices and cost-cutting measures forced them to eliminate the capacity to engage in exploratory activities. The firms had generally minimized their front office staff and focused on the day-to-day operations of coordinating logistics, purchasing supplies, liaising with customers and managing their employees. 
Suppliers were key inputs into the innovative processes of firms in this category. One interviewee emphasized: "[Our machinery equipment suppliers are] probably the most important input into our processes, and we rely on them heavily to innovate and help solve problems in our products" (Interview I225). They provided not only new equipment, but also assistance on how to improve processes with respect to the use of machinery. According to our interviews, the drive to innovate for short-run contract fabricators could come from the failure to compete for jobs, as one founder suggested: "You are going to go out and look for better, cheaper ways of doing things, based on the fact that you are not getting success in the bidding process" (Interview I220). From a regional perspective, the downside to this kind of innovating-by-purchasing was that firms became capital-intensive and reduced their workforce over time. We encountered one firm that had expanded its capacity to provide metal coating by making capital investments in automated equipment, but found that customers backed out of their agreements in the wake of the financial crisis. It becomes an obvious risk for these firms to increase their capacity to attract new customers and retain enough existing business to justify these expenditures.

Most of the supplies needed for day-to-day operations were raw materials, but these suppliers were not important beyond the acquisition of information regarding pricing. As one interviewee pointed out graphically: “[M]ost suppliers do not give a damn what we do. They are just providing you with material. It is generic stuff. You call them, they tell you they have it or they do not" (Interview I202). While these firms credited their customers with demanding innovation, suppliers - particularly the local sales and support divisions of international CNC machinery manufacturers - were necessary in helping them to identify equipment needed to meet customer demand, to install new equipment and to train staff (e.g. Gertler, 2004). This kind of capital investment drew heavily on resources from outside the region, but increased the capabilities of firms inside. From a regional re-bundling perspective, this kind of process 
innovation through capital investments offers limited competitive advantage over other firms (and other regions) that also invest in the same kinds of equipment (Figure 2); yet, it shows that these firms were adaptive and generally willing to extend their technological capabilities and move into new directions. These firms had some competence to innovate and support incremental regional re-bundling.

(c) Innovation through Customer Consultation. We encountered a few firms (5 of 40) which operated similarly to those 8 firms manufacturing according to customer specifications, but were set apart by the fact that they consulted on the original product design for a few key customers. From this consultation, the firms developed an internal capacity to provide design feedback to ease manufacturing, thereby lowering the production costs. Through such exchanges, the firms became increasingly involved in early-stage product design. This was not necessarily a capability demanded by all clients, but some of those firms, which were engaged in collaborative design processes, became also good at solving manufacturing problems for other clients at a faster pace than their competitors, increasing product turn-around times.

For example, one of the firms interviewed started off manufacturing tooling and moulds for PTE bottle manufacturing, but over time grew to incorporate design consultation. It developed a prototype-testing capacity to ensure customers were choosing the cheapest resins for their products. The firm increasingly leveraged this prototyping capability into a broader design capacity, allowing the firm to create and produce the bottle designs. As the chief engineer suggested: "When we started out, we used to just build one part of the tooling. Now we have taken the same industry and we do everything. We do the equipment, we do the prototyping ... we have made it so that we are the one source as far as the bottling industry is concerned. Every year, we try to expand on what we can offer our clients" (Interview 203). The design and prototyping capacity was expanded into an $R \& D$ program allowing the firm to test the viability 
of bio-plastic-based resins, which they hoped to commercialize and offer to customers that were looking to produce environmentally-friendly products. This is an extreme example of a firm that managed to radically reconfigure itself from a $\mathrm{CNC}$ machine shop into a firm with a broader product offering. To extend its R\&D activities into bio-plastics, the firm worked very closely with resin suppliers who had an interest in seeing their raw plastic resins being commercialized on a broader basis.

More generally, firms of this type of collaborative and interactive innovation help strengthen the value chain by developing their own novel products, as well as by assisting other firms in developing new products. Innovation driven by such practices offers robust opportunities for re-bundling in ongoing adjustments and improvements by virtue of strengthened value chains and the potential for novel product development. Our case study clearly indicates that a necessary condition for innovation through customer consultation is the firm-specific knowledge to provide useful feedback on the manufacturability of part designs and openness of the customers to receive feedback. It should be reiterated, however, that firms indicated that this capacity developed with just one or two clients and became a firm competence through these few significant customer relationships.

(d) Innovation through Integrated Manufacturing and Research Capabilities. We further encountered a number of firms that explicitly moved beyond the point of providing feedback on the manufacturability of products (12 of 40 firms). They extended their manufacturing activities and became systematically involved in early-stage product design with long-term customers. Over time, they developed broader manufacturing and research capabilities and created at least one division that produced their own designs. This kind of build-up of knowledge from providing feedback on the manufacturability of parts to the creation of new products is an 
example of ongoing re-bundling at the firm level that led to the development of new products and a constant reconfiguration of the resource base (Figure 2).

One of the few firms interviewed with fully integrated manufacturing capabilities was the maker of several national brands of outdoor cooking appliances and barbeques. The firm was one of the most successful firms in the region and its innovation processes were based on internal competencies. They drew little benefit from the region other than access to a strong labor pool. The firm used generic and simple manufacturing processes - iron and steel forging - where labor represented only a small fraction of their costs and much of the firm's competitiveness derived from design capabilities. The primary benefit the firm received from the surrounding region was its flagship store in a nearby location that provided direct market feedback, as the regional population mirrored the target customer range (primarily middle-class homeowners).

One of the challenges the firm faced was the trend toward rising manufacturing costs. Further, customers seemed to expect more product features over time, which increased product complexity. At one point, the firm tried to hire design firms to develop new products for them, but the contract designers did not understand the limitations of the existing manufacturing capabilities. They failed to incorporate the current tooling and did not utilize enough of the legacy parts from other models, complicating the production lines and the distribution of replacement parts. By re-establishing control over the design processes, the firm was able to ensure that new products retained a high degree of similarity to previous and concurrent models, thereby reducing production costs. Since the firm produces numerous new models each year, and not every model sells well to consumers, having a high degree of similarity across product lines allows the firm to adjust quickly to demand trends. This is a strategy shared with other firms of this type. 
This firm's experience as an integrated manufacturer illustrates the value of having an internal design department that understands the practical needs of the manufacturing process. Despite this success, the demographic trends suggested that the firm will be increasingly under pressure to seek ways to lower their labor costs, which could lead to un-bundling processes in the future, as the CEO suggested. At this point, however, firms of this type had a distinct manufacturing and research competence. Due to their learning and integrated processing and design experience, they had become quite flexible and were able to engage in ongoing rebundling activities during periods of constant changes and crisis (Bathelt and Boggs, 2003).

(e) Innovation as Diversification Strategy. A subgroup of 10 firms, which were already assigned to one of the other firm types, also indicated that they had made conscious efforts to diversify their operations. This strategy was most common amongst fabrication firms working in the automotive sector. Of the $12 \mathrm{OEMs} /$ firms that reported working in the automotive industry (Table 6), 7 said that they aimed to become less reliant on automotive customers and had already invested in diversification processes before the global financial crisis. The comment of one interviewee that "[y]ou might not be familiar with the automotive industry, but it is nerveracking" (Interview I236) is representative of the opinions of the firms which were suppliers in this sector: "It is [a] challenge every year to come up with cost savings on each and every component you are producing ... [The automobile producers] are all demanding a $10 \%$ reduction. It is a tough business" (Interview I240).

The challenges and demands of the automotive sector, however, also benefited some of the firms by forcing them to improve their efficiency despite the request for year-over-year cost cutting that put a significant strain on the firms' capabilities. This resulted in a search for opportunities to diversify. ${ }^{8}$ A particularly poignant example of this was a tier-two automotive supplier that specializes in transmission systems. The firm sought to diversify by purchasing the 
patents for an off-road suspension dampening system, primarily used on large trucks in mining, forestry and the military sector. Through this, the firm tried to re-bundle its existing resources while gradually adding on new ones to enter new markets. Other firms took the approach of remaining at current capacity, but decreasing the percentage of work in the automotive sector. Four firms mentioned wind turbine manufacturing, aerospace and medical devices as areas that they engaged more heavily in an effort to diversify and decrease their dependence on the automotive industry. ${ }^{9}$

Although several firms shifted away from the automotive value chain, some interviewees suggested that, in the end, they benefited from prior interaction with automotive firms. Through this, they developed internal competencies to continuously improve their own capabilities. One firm, specializing in manufacturing for an OEM, commented as follows: "In order to be a supplier for someone like ... [this OEM manufacturer], you need to have a very strong quality program to drive down costs every year. So I think that they have made us a better company" (Interview I229). Beyond providing encouragement to drive down costs in production, the firms also improved substantially in their ability to design products. As a consequence, OEMs turned to them for more assistance in reducing costs. A tier-two supplier commented: "We have become more involved in ... [providing] feedback and recommendations on product design, and how [a product] could be redesigned from the beginning to drive out costs at the end ... There are design limitations that the designers need to understand, and that helps reduce costs" (Interview 225). An interviewee at a tier-one automotive supplier speaking on the same topic emphasized the necessity to combine research and manufacturing in innovation:

"If the engineers are allowed to just go out and design it in [their] own space without looking at the manufacturing side of things, then to take those drawings and to say, 'make this and drive costs out of it', you have wasted $60 \%$ of your 
possible cost savings. So, we tie in the manufacturing guy with our design engineers. We are big believers in design-for-manufacture" (Interview 223).

As a result, the firm began to design and manufacture its own products through a consumer products division, although it was originally a tier-two parts manufacturer making simple fuel pump components. The firm made small improvements in the parts they manufactured that helped increase fuel efficiency in the end product. Due to past successes, the firm quickly expanded its design capabilities through internal developments and acquisitions (such as purchasing an automotive design firm in Detroit). The firm is particularly conscientious about creating regional supplier-customer networks and helping their suppliers grow with the firm. This attitude, along with the mobilization of resources external to the region, created the potential for more radical re-bundling processes taking hold regionally, in the form of knowledge spillovers along supplier-customer linkages (Figure 2). Certainly, this helped create a setting that fosters ongoing learning, adaptation and adjustment processes.

In general, most firms interviewed were proceeding with operations as usual and did not plan on changes in their supplier-customer linkages in response to the global financial crisis. Many firms remained internally innovative and developed even stronger collaborative relationships within their value chains, as indicated by their increased involvement in the design of products. This involvement in design increased the potential to adjust to external economic pressures and had further positive effects on other firms. As we will discuss in the next section, the global economic crisis was, for these firms, just one more crisis they had to weather over the past decade. 


\section{Global Crisis and Regional Innovation}

\subsection{Firm Responses to the Crisis}

Generally, our interviewees confirmed they were negatively affected by the 2008 financial crisis. Two thirds of the managers who were asked about the effects of the crisis $(22$ of 30 firms) suggested that their business had significantly decreased due to the crisis' sudden nature. Of these firms, all but two reported losses of sales and/or customers due to either cutbacks on orders or the bankruptcy of their clients, particularly in the automobile industry. As one plant manager of a tier-two supplier said: “The 'little three' as I call them [now] were 75\% of our business, but now they have stopped dead. So they are not doing anything. Any work we are doing is for the [Japanese] transplants" (Interview I224). Other firms, ranging from the largest industrial employer in the region to small grinding and plating shops with only a few employees, mentioned similar, sudden drops in orders.

Many of the firms avoided a steep decline in the crisis due to existing contracts with partners that ensured stable sales (see, also, Fuchs and Kempermann 2010). This was true even for some firms supplying the automotive sector. ${ }^{10}$ Others reported strong sales to sectors not as heavily affected by the crisis, such as Alberta's oil industry or the alternative energy sector (e.g. Spears, 2010). The firms typically responded to the crisis in three ways: by laying off workers; by finding internal efficiencies and cost savings; and/or by diversifying their markets and customer bases:

(a) Job Decline. As expected, the most common strategy to deal with the decline in sales was to eliminate jobs. Of the 22 firms that were explicitly asked about the crisis and responded that they were affected by it, 12 confirmed that they laid off workers as a direct result of the crisis, ${ }^{11}$ and many others were significantly smaller than they were three years ago. Some of these layoffs were characterized as temporary, and several firms had taken advantage of 
provincial programs that used unemployment insurance to pay for three days of salary a week, with the company paying the remaining two days. Overall, however, layoffs were smaller than expected, and many interviewees mentioned that they would try to delay laying off qualified personnel for as long as possible in order to preserve their valuable human capital and institutional memory. This is a trend generally not expected in an economy that is often classified as a liberal market economy.

(b) Increasing Efficiency. Many firms depended on finding internal efficiencies and reductions in manufacturing waste to offset lower sales. However, this strategy was mostly seen in larger firms with sufficient cash reserves necessary for internal reorganization. Two firms were working towards implementing leaner, more flexible material procurement and tracking systems. Smaller firms, and those already suffering heavy losses before 2008 , lacked the internal resources to undertake intense efficiency improvement measures and were forced to rely mainly on cutting labor costs to deal with lower order volumes.

(c) Diversification. Firms with primary customers in declining industries, such as automotive, construction or resource extraction, emphasized diversification as a critical strategy (Hamilton, 2009). One firm began a strategic movement away from heavy industrial fabrication towards architectural steel, while others pursued markets that were perceived to be either growing or holding steady. However, as suggested above, larger firms with in-house R\&D and engineering competencies were better equipped for such changes. Smaller firms or firms with large capital investments in specialized equipment - especially small tool and die and fabrication shops - lacked the capacity to quickly re-bundle internal and external resources and enter more diverse markets. 


\subsection{Impact of the Financial Crisis on Innovation}

In an economic crisis marked by declining sales to long-term customers, innovation is a key strategy for opening up new markets and meeting the clients' cost-cutting demands, but innovation is difficult to implement or sustain in the midst of an economic crisis. Almost without exception, firms acknowledged innovation as a main survival tool in a faltering economy. Many firms saw new products or lower costs as essential for finding new customers and maintaining existing ones. Yet, most of the managers and owners, particularly amongst the fabricators and treatment and material preparation firms, did not view themselves as particularly innovative. They regarded innovation as internally directed $\mathrm{R} \& \mathrm{D}$ projects aimed at creating new products. Lacking their own R\&D divisions, these firms did not perceive innovation as a core competence. When broadening the discussion to the implementation of efficiency measures, reducing turnaround times and the reduction of waste, it became clear that many firms in the traditional manufacturing sector were indeed innovative and regarded themselves as quite competent at reducing costs and improving their manufacturing routines. Similar patterns of innovation oriented towards internal efficiencies rather than product development were also noted in studies of other regions dependent on traditional manufacturing (Kaufmann and Tödtling, 2000; Rutherford and Holmes, 2007; Hirsch-Kreinsen, 2008).

As suggested by the re-bundling perspective (Bathelt and Boggs, 2003), a crisis is simultaneously the best and worst time for innovation. Innovation requires sufficient human capital to find ways to increase production or reduce costs, as well as sufficient financial capital to either bring in outside talent or to purchase necessary equipment (Bathelt, 2009). During the crisis, some firms found that customers were no longer willing to invest in up-front redesign to secure cost savings down the line. As one manager put it: "What we think we do is bring innovative processes to firms ... Everything has come to a standstill with new business. 
Companies are dealing with the crisis and are not looking to change. They do not want to change sources. So, that limits our ability to grow [our] market" (Interview I209). Many small firms in our study, especially fabricators, worked with their clients to find new materials and designs that reduced production costs. The firms that developed these new capabilities through ongoing customer consultation in manufacturing and design had done this before the crisis.

Many of the smaller fabrication firms that relied on the purchase of new equipment to introduce new firm capabilities were cautious about making large capital investments in this uncertain period. The owner of a small production shop said: “... we were going to bring in a new product at a lower price point due to the economic conditions ... [but] when we had that second drop [in the market], we were a bit more challenged to make that capital outlay" (Interview I234). The introduction of new equipment is a form of innovation both in evaluating which equipment to buy and integrating it into an existing production line. The economic crisis made it harder for small firms without large cash reserves to justify such capital outlays.

Larger firms, especially OEMs with integrated manufacturing and research capabilities, were more likely to see the crisis as an opportunity to lower costs or find new clients. Several firms noted that because of the crisis, costs of capital goods and raw materials decreased. A total of 5 firms, including some of the largest in our sample, reported taking advantage of the downturn in the economy by beginning projects designed to increase the range of products and services they offer. Firms able to undertake such projects saw themselves as well positioned to rapidly expand after the crisis. These forms of re-bundling activities were only possible when a firm had sufficient internal reserves or access to external credit.

Innovation in traditional manufacturing industries is never an easy task. In a crisis, firms are under increased pressure to reduce their costs to retain customers and make up for lost ones. Simultaneously, less credit is available for expansion. In our study region, savings were more 
often found in eliminating waste and inefficiencies in the manufacturing process by either changing the materials used, by reducing the time to make a product or by automating laborintensive processes. Nearly all firms reported that they eliminated inefficiencies for many years in response to previous crises and downturns in the regional economy. Some respondents found that there were no inexpensive or easy options left for reducing waste that were not already adopted.

\subsection{Innovation due to Prior Crises Adjustments}

Although we expected that the recent global financial crisis would stand out as a major rupture in economic development, firms saw this crisis in the context of prior economic ruptures and presented their current actions in the light of innovations that resulted from former crisis adjustments (see, also, Fuchs and Kempermann, 2010; Hahn, 2010). The current financial crisis was only one of several crises and downturns the region's manufacturing sector experienced since the 1990s. While the Canadian Dollar was worth between 0.60 and 0.80 US-Dollars in the 1980s and 1990s, helping Canadian manufacturers remain competitive, the early 2000s saw a sharp appreciation, driving up the relative price of Canadian manufacturers selling to the US. This rise in the Canadian Dollar made the region's manufacturing firms, in the words of a plant manager, “... less attractive, instead of really attractive" (Interview I229). Another manager supplying to the automotive sector noted that, "[i]f you see the [Canadian] Dollar trading at 0.68 [US-Dollars] when the pricing is determined, and it moves to 0.81 [US-Dollars], that is a huge difference in an industry that does not allow for large margins" (Interview I209). At the same time, of course, the rise in the Canadian Dollar decreased the relative price of supplies and equipment from the US, partially offsetting the problems with exports.

Beyond the effects of currency rates, manufacturers throughout the world were hit hard by an unprecedented increase in the cost of commodities such as iron, steel and aluminum. 
Between 2005 and 2007, the International Monetary Fund's international index of industrial commodities increased by over $70 \%$ before dropping off significantly in the wake of the global financial crisis (International Monetary Fund, 2010). Consequently, many firms saw customers shift their purchases to low-cost producers located in Asia and South America. These two crises, the shift in the Canadian currency and price increases in industrial inputs, combined with the recent financial crisis and global economic downturn, represent almost a complete decade of continuous crises in the Southern Ontario manufacturing sector. One manager succinctly summarized this situation:

"This is our third crisis in a row. There's the current economy downturn that is more systemic through the economy, but we were also affected by the Canadian Dollar moving to par, and the increase in steel costs. So, we've been hit by a series of three crises over three years. The steel pricing doubled, so when the price of the commodity is $20 \%$ to $80 \%$ of the cost of the finished product and you get a doubling in the commodity price, you see a doubling in the cost of the part. Our situation was not unique in the industry. The price the consumer paid did not change ... That was a huge issue; it continues to be a big issue. The parts we manufacture are not products that change on an annual basis" (Interview I209).

The strategies of regional firms in traditional manufacturing to gain control of the design and innovation processes were, thus, a consequence of earlier economic crises. The responses of many of our interviewees suggest that innovation strategies were chosen or modified in reaction to these crises. This included tendencies to play a more active role in customer-specified manufacturing; increasing customer involvement in incremental innovation; and the use of innovation as a driver of diversification. This leads us to conclude that adjustments to prior crises have strengthened the adaptability and reduced the vulnerability of the region's traditional manufacturing sector, increasing its "resiliency" in the face of larger structural crises. In response to both this and previous crises, firms have re-bundled their existing internal resources 
and attempted to acquire new external resources to re-orient themselves to deal with new economic realities on an ongoing basis (Figure 2; Bathelt and Boggs, 2003).

\section{Conclusions}

This paper has argued that regional economic development trajectories are routinely ruptured by crises of different nature. Ruptures due to the global financial crisis set off in 2008 had a strong impact on the existing regional transaction linkages and networks, potentially leading to an abrupt halt in the trajectory or triggering path-shifting processes. The argument developed in this paper is that whatever the restructuring or adjustment processes may be, they necessarily require an ability to mobilize new and recombine existing regional and extra-regional agents and resources into new, more or less coherent, development frameworks to eventually overcome the crisis.

Of the four scenarios of re-bundling discussed in this paper, case $\mathrm{c}$ that emphasizes the role of ongoing re-bundling, innovation and pro-active adjustments to crises seems to best describe the restructuring in the traditional manufacturing sector of the Kitchener and Guelph metropolitan regions (Figure 2). Although investigating re-bundling processes at a firm level, an aggregate view allows us to draw some conclusions about the regional consequences in CTT. There is no evidence that either skilled industrial workers or R\&D specialists have left the region after the initial shock; indeed regional data points toward reinvigorated growth as, for instance, the number of employees in the Kitchener MSA manufacturing sector increased by $17.6 \%$ from 48,200 in August 2009 to 56,700 one year later (Statistics Canada, 2010b). There is also no indication of continuing un-bundling after some initial firm closures. Nor have key firms like Linamar or Toyota divested in the area.

Many of the firms that were affected by the economic problems of the past decade attempted "to innovate their way out" by either expanding their current array of products and 
services or finding ways to service new markets and industries using mostly existing competencies. Firms used a combination of their own internal resources along with other resources available in the community to make this adjustment. Wider international customer and/or corporate networks helped these re-bundling activities. Of course, not all firms were able to adjust successfully and had to implement cost cutting measures like layoffs and strategic exists from competitive markets. Overall, however, the region's trajectory points toward a branchingout process where new structures develop based on existing competencies, leading in our case to continued diversification. With respect to adjustment processes, our study reveals some unexpected findings that challenge existing explanations of economic development in our study region:

(a) CTT was and still is strongly shaped by traditional manufacturing industries and is not well characterized as a "post-industrial" economy.

(b) The region's traditional manufacturing sector was hit substantially by the global financial crisis, but restructuring processes and layoffs were not as severe as one could have expected. The region remains a strong hub for such manufacturing activities.

(c) Although about one third of the firms interviewed were not engaged in active innovation, another third had much or full control of the innovation and design process, suggesting that there is substantial innovation and adjustment potential in the region's traditional industries.

(d) In terms of the spatiality of innovation, results are somewhat mixed. By no means, however, did we find that innovation linkages were primarily local or regional in character (Bathelt et al., 2011). We expected that some of the smaller fabrication shops would be closely tied to the region, supplying local OEMs, but this was rarely the case. Several of these shops serviced important clients throughout Southern Ontario and the US 
Mid-West. The firms closely tied to the region were located there due to low costs in shipping their products to major market regions. Some outstanding exceptions existed though, such as one tier-one automobile supplier that explicitly developed a supplier clustering strategy. ${ }^{12}$

(e) In terms of "regional resilience", firms in traditional manufacturing industries were not as strongly affected by the financial crisis as expected. As shown in our research, firms gained adaptability in their responses to prior crises, especially related to new innovation strategies, integrated manufacturing and research capabilities, stronger customer involvement, as well as increased control over the innovation and design process. These findings, although based on a relatively small sample of firms, could have wideranging policy implications, particularly for economic development policies that accept the sacrifice of traditional manufacturing sectors for the benefit of support for high technology industries. Our study shows that traditional manufacturing firms are not necessarily less resilient towards economic crises than other industries. As demonstrated in CTT, traditional manufacturing firms can be quite innovative and flexibly adjust to new market situations if they engage in ongoing re-bundling activities involving incremental improvements and adjustments, the acquisition of new resources, and related diversification and renewal processes. This suggests that such regions do not necessarily have to develop a completely new economic make-up, but may be able to remain competitive based on existing competencies that enable dynamic adaptability. It might, in fact, be more effective to concentrate policy activities to support existing, more traditional industries in individual and collective learning, innovation and diversification activities than to focus on creating a completely new set of capabilities and industries (Boschma and Lamboy, 1999). This is especially important in regions, such as CTT, which have a larger traditional manufacturing sector. When aggregated over the entire region, 
ongoing incremental and discontinuous shifts in firm practices and routines involving internal and external resources, may contribute to developing strong regional re-bundling capabilities and ongoing growth after the crisis. Our study region indeed indicates a reinvigorated economic performance in 2009 and 2010.

As a consequence of these findings, we have to reevaluate the suggestions by Martin and Florida (2009) in a recent economic consulting report about the future development of Ontario, prepared for the provincial government. In this report, Martin and Florida (2009) suggest to focus government support on the growth of the "creative economy", while giving up support for traditional manufacturing industries. Notwithstanding the criticism of this approach, the suggestion to completely ignore traditional manufacturing industries appears premature given the evidence provided in this paper. In contrast to this view, the Ontario Manufacturing Council $(2010,9)$ concludes that "[t]he manufacturing sector will need to play a central role in reversing Canada's underperformance in innovation." The manufacturing sector in the Kitchener and Guelph metropolitan regions not only covers a substantial part of the regional economy, it also has substantive innovative potential and has successfully adapted to both the past and current crises, thus increasing its resistance towards ruptures in the future. In fact, our research suggests that specific policy programs for traditional manufacturing industries - which focus on supporting knowledge exchange; strengthening research, development and design competencies; investing in human capital development; and building wider international producer-user networks - could be decisive to help firms engage in ongoing adaptation and innovation by reconfiguring existing and new resources into new coherent development paths.

\section{Acknowledgements}

This paper, to which all authors contributed equally, was presented in 2010 at the Annual Meeting of the Association of American Geographers in Washington, DC, the IGU Conference 
on "Industrial Transition - New Patterns of Production, Work, and Innovativeness in GlobalLocal Spaces" in Cologne, and the European Urban and Regional Studies Conference on "Repositioning Europe in an Era of Global Transformations" in Vienna. We would like to thank Ron Boschma, Susan Christopherson, Andy Cumbers, Peter Dörrenbächer, Martina FromholdEisebith, Martina Fuchs, Arne Isaksen, Arnould Lagendijk, Rünno Lumiste, Andy Pike, Mike Taylor, Alain Thierstein, Franz Tödtling, Jici Wang and Stefan Wetzstein, as well as the anonymous Reviewers, for valuable comments and feedback. Financial support by the Canadian Social Sciences and Humanities Research Council and the Canada Research Chair Program is greatly appreciated.

\section{Bibliography}

Amin, A. (2004): Regions unbound: towards a new politics of place. Geografiska Annaler 86 B: $33-44$.

Bagchi-Sen, S. (2001): Product innovation and competitive advantage in an area of industrial decline: the Niagara region of Canada. Technovation 21: 45-54.

Bathelt, H. (2009): Re-bundling and the development of hollow clusters in the East German chemical industry. European Urban and Regional Studies 16: 363-381.

Bathelt, H. and Boggs, J. S. (2003): Towards a reconceptualization of regional development paths: is Leipzig's media cluster a continuation of or a rupture with the past? Economic Geography 79: 265-293.

Bathelt, H. and Hecht, A. (1990): Key technology industries in the Waterloo region: Canada's Technology Triangle (CTT). Canadian Geographer 34: 225-234.

Bathelt, H., Kogler, D. F. and Munro, A. K. (2010): A knowledge-based typology of university spin-offs in the context of regional economic development. Technovation 30: 519-532. 
Bathelt, H., Kogler, D. F. and Munro, A. K. (2011): Social foundations of regional innovation and the role of university spin-offs. Industry and Innovation 18 (5): forthcoming.

BMO Capital Markets (2008): Waterloo Region and Guelph: Short-term Pain, Long-term Gains. Toronto: Bank of Montreal, Economic Research (URL: http://www.techtriangle.com/UploadedFiles//2008-02-12_BMO_WaterlooGuelph_Econ_Outlook.pdf, date accessed February 25, 2008).

Boschma, R. and Frenken, K. (2011): Technological relatedness and regional branching. In: Bathelt, H., Feldman, M. P. and Kogler, D. F. (eds.): Beyond Territory: Dynamic Geographies of Knowledge Creation, Diffusion, and Innovation. London: Routledge, forthcoming.

Boschma, R. A. and Lambooy, J. G. (1999): Evolutionary economics and economic geography. Journal of Evolutionary Economics 9: 411-429.

Bramwell, A. and Wolfe, D. A. (2008): Universities and regional economic development: the entrepreneurial University of Waterloo. Research Policy 37: 1175-1187.

Bunkley, N. (2008): Another month of miserable auto sales. The New York Times. December 2, p. B1.

Chapman, K., MacKinnon, D. and Cumbers, A. (2004): Adjustment or renewal in regional clusters? A study of diversification amongst SMEs in the Abdeen oil complex. Transactions of the Institute of British Geographers NS 29: 382-396.

Christopherson, S., Michie, J. and Tyler, P. (2010): Regional resilience: theoretical and empirical perspectives. Cambridge Journal of Regions, Economy and Society, 3: 3-10.

Dosi, G. (1988): The nature of the innovative process. In: Dosi, G., Freeman, C., Nelson, R. R., Silverberg, G. and Soete, L. L. G. (eds.): Technical Change and Economic Theory. London, New York: Pinter, pp. 221-238. 
Eisenhardt, K. M. (1989): Building theories from case study research. Academy of Management Review 14: 532-550.

Engelen, E. and Faulconbridge, J. (2009): Financial geographies - the credit crisis as an opportunity to catch economic geography's next boat? Journal of Economic Geography 9: 587-595.

English, J. and McLaughlin, K. (1983): Kitchener: An Illustrated History. Waterloo: Wilfrid Laurier University.

Feldman, M. and Francis, J. L. (2006): Entrepreneurs as agents in the formation of industrial clusters. In: Asheim, B., Cooke, P. and Martin, R. (eds.): Clusters and Regional Development: Critical Reflections and Explorations. London, New York: Routledge, pp. $115-136$

Florida, R and Martin, R. (2009): Ontario in the Creative Age. Consulting report, Toronto: Martin Prosperity Institute.

Frenken, K., Van Oort, F. and Verburg, T. (2007): Related variety, unrelated variety and regional economic growth. Regional Studies 41: 685-697.

Fuchs, M. and Kempermann, H. (2010): Flexible Specialization as Locational Advantage in the Economic Crisis? Examples from the German Mechanical Engineering Industry. Paper presented at the IGU Conference on "Industrial Transition - New Patterns of Production, Work, and Innovativeness in Global-Local Spaces" in Cologne, May 20-22.

Gertler, M. S. (2004): Manufacturing Culture: The Institutional Geography of Industrial Practice. Oxford, New York: Oxford University Press.

Grabher, G. (1993): The weakness of strong ties: the lock-in of regional development in the Ruhr area. In: Grabher, G. (ed.): The Embedded Firm: On the Socioeconomics of Industrial Networks. London, New York: Routledge, pp. 255-277. 
Grabher, G. and Stark, D. (eds.) (1997): Restructuring Networks in Post-socialism: Legacies, Linkages, and Localities. Oxford: Oxford University Press.

GuelphMercury.com (2009): 500 Collins \& Aikman jobs lost. January.

Hahn, C. (2010): The Transition of the Automotive Sector as a Catalyst for the Mobilization of Regional Knowledge? The Case of the "Greater Region SaarLorLux". Paper presented at the IGU Conference on "Industrial Transition - New Patterns of Production, Work, and Innovativeness in Global-Local Spaces" in Cologne, May 20-22.

Hamilton, T. (2009): Green machining. Toronto Star, November 21.

Hassink, R. (2005): How to unlock regional economies from path dependency? From learning region to learning cluster. European Planning Studies 13: 521-535.

Hassink, R. (2010). Regional resilience: a promising concept to explain differences in regional economic adaptability? Cambridge Journal of Regions, Economy and Society 3: 45-58.

Hirsch-Kreinsen, H. (2008): “Low-tech” innovations. Industry and Innovation 15: 19-43.

Holmes, J. Rutherford, T. and Fitzgibbon, S. (2005): Innovation in the automotive tool, die and mould industry: a case study of the Windsor-Essex region. In: Wolfe, D. and Lucas, M. (eds.): Global Networks and Local Linkages: The Paradox of Cluster Development in an Open Economy. Kingston, Ontario: McGill-Queen’s University Press, pp. 119-154.

International Monetary Fund. (2010): IMF Primary Commodity Prices (URL: http://www.imf.org/external/np/res/commod/index.asp, date accessed April 11, 2010).

Kaufmann, A., Lehner, P. and Tödtling, F. (2003): Effects of the Internet on the spatial structure of innovation networks. Information Economics and Policy 15: 402-424.

Keenan, G. (2009): Parts maker Lear files for protection. Globe and Mail, Report on Business, July 10. 
MacKinnon, D., Cumbers, A., Pike, A., Birch, K. and McMaster, R. (2009): Evolution in economic geography: institutions, political economy, and adaptation. Economic Geography 85: 129-150.

Malecki, E. J. (2009): Geographical environments for entrepreneurship. International Journal of Entrepreneurship and Small Business 7: 175-190.

Martin, R. (2010): The 2009 Roepke Lecture in Economic Geography - Rethinking regional path dependence: from lock-in to evolution. Economic Geography 86: 1-27.

Martin, R. and Sunley, P. (2006): Path dependence and regional economic evolution. Journal of Economic Geography 6: 395-435.

Myrdal, G. (1957): Economic Theory and Underdeveloped Regions. London: Duckworth.

Neffke, F., Henning, M. and Boschma, R. (2011): How do regions diversify over time? Industrial relatedness and the development of new growth paths in regions. Forthcoming in Economic Geography, DOI: 10.1111/j.1944-8287-2011.01121.x.

Nelson, R. R. and Winter, S. G. (1982): An Evolutionary Theory of Economic Change. Cambridge, MA: Harvard University Press.

Ontario Manufacturing Council (2010): 2010: A Better Year for Ontario Manufacturing. Report, December 2010, Toronto (URL: http://on.cme-mec.ca/download.php?file=gi99oczy.pdf, date accessed December 29, 2010).

Owen-Smith, J. and Powell, W. W. (2004): Knowledge networks as channels and conduits: the effects of spillovers in the Boston biotechnology community. Organization Science 15: 221.

Park, S. O. (2010): Transformation of Regional Governance Structures and Economic Dynamics in the East Asian Countries. Paper presented at the Annual Meeting of the Association of American Geographers in Washington, DC, April 14-18.

Penrose, E. (1959): The Theory of the Growth of the Firm. Oxford: Oxford University Press. 
Penrose, E. (1997): The theory of the growth of the firm. In: Foss, N. J. (ed.): Resources, Firms and Strategies: A Reader in the Resource-based Perspective. Oxford, New York: Oxford University Press, pp. 27-39.

Perry, A. (2009): Meet our post-industrial Waterloo. Toronto Star, March 21, p. B2.

Pike, A., Dawley, S. and Tomaney, J. (2010): Resilience, adaptation and adaptability. Cambridge Journal of Regions, Economy and Society 3: 59-70.

Rigby, D. L. and Essletzbichler, J. (1997): Evolution, process variety, and regional trajectories of technological change in US manufacturing. Economic Geography 73: 269-284.

Rutherford. T. and Holmes, J. (2007): "We simply have to do that stuff for our survival": labour, firm innovation and cluster governance in the Canadian automotive parts industry. Antipode 28: 194-221.

Rutherford, T. and Holmes, J. (2008): Engineering networks: university-industry networks in southern Ontario automotive industry clusters. Cambridge Journal of Regions, Economy and Society 1: 247-264.

Schoenberger, E. J. (1991): The corporate interview as a research method in economic geography. Professional Geographer 43 (2): 180-189.

Scott A. J. (1988): New Industrial Spaces: Flexible Production Organization and Regional Development in North America and Western Europe. London: Pion.

Scott, A. J. (1998): Regions and the World Economy: The Coming Shape of Global Production, Competition, and Political Order. Oxford, New York: Oxford University Press.

Simmie, J. and Martin, R. (2010): The economic resilience of regions: towards an evolutionary approach. Cambridge Journal of Regions, Economy and Society 3: 27-42.

Spears, J. (2010): Guelph gets new solar panel plant. Toronto Star, August 11. 
Statistics Canada (2006): Census of Canada 2006: Profile Series, Cumulative Files. Catalogue No. 94-581-XCB2006001 and 94-581-XCB2006004. Ottawa: Statistics Canada.

Statistics Canada (2008): Canadian business patterns, June 2008: Establishment Counts by CMA, Industry Sector (NAICS 2007, 2-digit) \& Employment Category (Number of Employees). Ottawa: Statistics Canada.

Statistics Canada (2009): CANSIM Tables 2820090 and 2055599. Labour Force Survey (LFS) Estimates. Ottawa: Statistics Canada.

Statistics Canada (2010a): Labor Force Historical Review. Catalogue No. 71F0004XVB. Ottawa: Statistics Canada.

Statistics Canada (2010b): CANSIM Table 2820056. Labour Force Survey (LFS) Estimates. Ottawa: Statistics Canada.

Statistics Canada (2010c): CANSIM Tables 2067453, 2067458 and 2067467. Labour Force Survey (LFS) Estimates. Ottawa: Statistics Canada.

Storper, M. and Walker, R. (1989): The Capitalist Imperative. Territory, Technology, and Industrial Growth. New York, Oxford: Basil Blackwell.

Taylor, M. (2000): Enterprise, power and embeddedness: an empirical exploration. In: Vatne, E. and Taylor, M. (eds.): The Networked Firm in a Global World: Small Firms in New Environments. Aldershot, Burlington: Ashgate, pp. 199-233.

Van Alphen, T. (2008): 1,200 Kitchener jobs going. Toronto Star, February 12.

Van Alphen, T. (2009): Linamar CEO sees new wave of auto parts failures. Toronto Star, October 20.

Van Alphen, T. (2010): Parts sector sputters in auto recovery. Toronto Star, September 17. Vinodrai, T. (2011): The dynamics of economic change in Canadian cities: innovation, culture, and the emergence of a knowledge-based economy. In: Bunting, T., Fillion, P. and 
Walker, R. (eds.): Canadian Cities in Transition: New Directions in the Twenty-First Century. 4th edition, Toronto: Oxford University Press Canada, forthcoming.

Welch, C., Marschan-Piekkari, R., Penttinen, H. and Tahvanainen, M. (2002): Corporate elites as informants in qualitative international business research. International Business Review 11: 611-628.

Wernerfelt, B. (1984): A resource-based view of the firm. Strategic Management Journal 5: 171180.

Wilding, C. (2010): Time for a regional strategy. Toronto Star, October 26. 


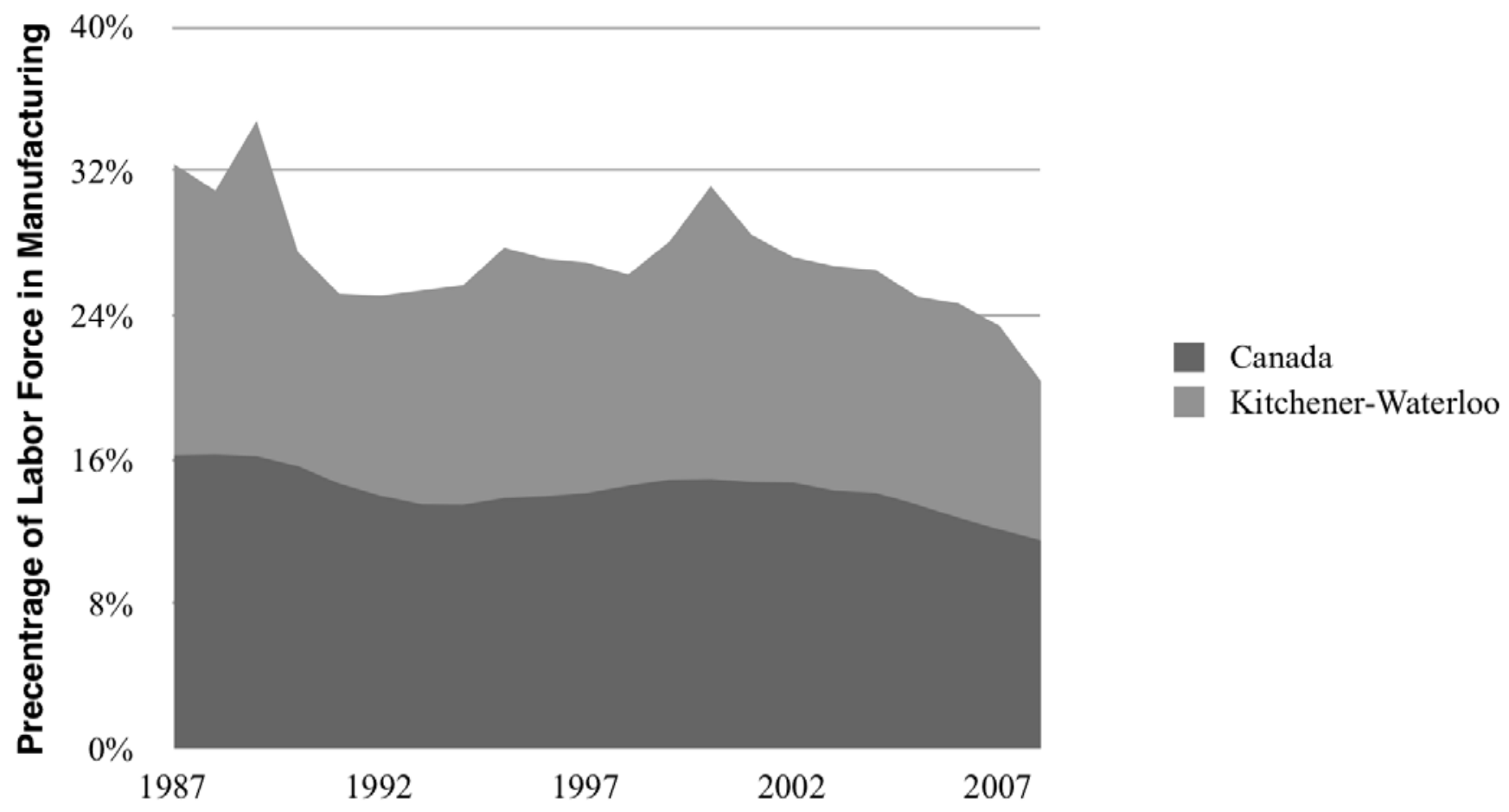

Figure 1: Percentage of the Canadian and Kitchener CMA Labor Force in Manufacturing Sectors, 1987-2007 (Source: Statistics Canada, 2010a) 


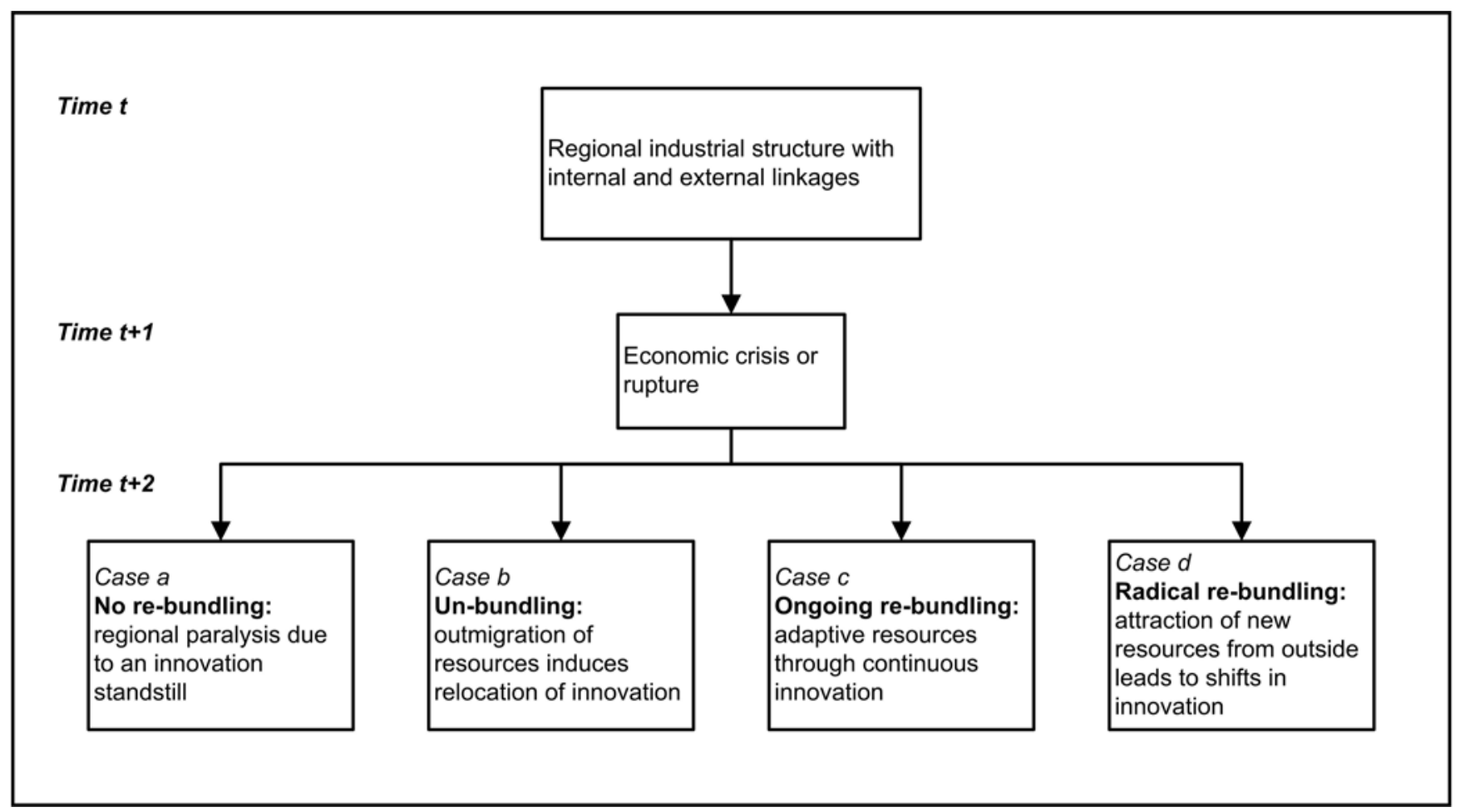

Figure 2: Regional Development Trajectories at the Crossroads: Ruptures and Re-Bundling 
Table 1: Number and Location Quotients (LQs) of Firms and Employees in CTT by Industrial Sector, 2008 (Source: Statistics Canada, 2008)

\begin{tabular}{|c|c|c|c|c|c|c|c|c|}
\hline \multirow{2}{*}{$\begin{array}{l}\text { Industrial Sectors by } \\
\text { NAICS Code }\end{array}$} & \multicolumn{4}{|c|}{ Kitchener CMA } & \multicolumn{4}{|c|}{ Guelph CA } \\
\hline & $\begin{array}{l}\text { Firm } \\
\text { LQ }\end{array}$ & $\begin{array}{l}\text { Number } \\
\text { of Firms }\end{array}$ & $\begin{array}{l}\text { Employee } \\
\text { LQ }\end{array}$ & $\begin{array}{l}\text { Number of } \\
\text { Employees }\end{array}$ & $\begin{array}{l}\text { Firm } \\
\text { LQ }\end{array}$ & $\begin{array}{l}\text { Number } \\
\text { of Firms }\end{array}$ & $\begin{array}{l}\text { Employee } \\
\text { LQ }\end{array}$ & $\begin{array}{l}\text { Number of } \\
\text { Employees }\end{array}$ \\
\hline 311 - Food & 1.02 & 96 & 2.34 & 7392 & 1.16 & 32 & 1.60 & 1308 \\
\hline Manufacturing & & & & & & & & \\
\hline $\begin{array}{l}312 \text { - Beverage and } \\
\text { Tobacco Product }\end{array}$ & 0.95 & 13 & 0.43 & 131 & 1.49 & 6 & 5.23 & 408 \\
\hline Manufacturing & & & & & & & & \\
\hline 313 - Textile Mills & 1.42 & 17 & 1.00 & 278 & 0.29 & 1 & 0.04 & 3 \\
\hline $\begin{array}{l}314 \text { - Textile Product } \\
\text { Mills }\end{array}$ & 1.53 & 31 & 2.89 & 1004 & 0.51 & 3 & 0.24 & 21 \\
\hline $\begin{array}{l}315 \text { - Clothing } \\
\text { Manufacturing }\end{array}$ & 0.60 & 34 & 0.80 & 668 & 0.48 & 8 & 1.74 & 376 \\
\hline $\begin{array}{l}316 \text { - Leather and Allied } \\
\text { Product Manufacturing }\end{array}$ & 1.52 & 11 & 0.87 & 63.5 & 1.41 & 3 & 0.91 & 17 \\
\hline $\begin{array}{l}321 \text { - Wood Product } \\
\text { Manufacturing }\end{array}$ & 1.33 & 79 & 0.73 & 1158 & 1.09 & 19 & 0.47 & 191 \\
\hline 322 - Paper & 0.91 & 13 & 1.28 & 1221 & 3.10 & 13 & 3.22 & 795 \\
\hline Manufacturing & & & & & & & & \\
\hline 323 - Printing and & 0.98 & 104 & 0.69 & 1069 & 0.96 & 30 & 0.67 & 267 \\
\hline $\begin{array}{l}\text { Related Support } \\
\text { Activities }\end{array}$ & & & & & & & & \\
\hline $\begin{array}{l}324 \text { - Petroleum and Coal } \\
\text { Product Manufacturing }\end{array}$ & 1.23 & 7 & 0.78 & 171 & 1.20 & 2 & 0.04 & 2.5 \\
\hline $\begin{array}{l}325 \text { - Chemical } \\
\text { Manufacturing }\end{array}$ & 1.24 & 53 & 1.09 & 1482 & 1.91 & 24 & 2.08 & 731 \\
\hline $\begin{array}{l}326 \text { - Plastics and Rubber } \\
\text { Products Manufacturing }\end{array}$ & 2.09 & 93 & 2.55 & 5347 & 1.84 & 24 & 1.31 & 709 \\
\hline $\begin{array}{l}327 \text { - Non-Metallic } \\
\text { Mineral Product }\end{array}$ & 1.25 & 49 & 2.14 & 2091 & 0.96 & 11 & 2.22 & 560 \\
\hline Manufacturing & & & & & & & & \\
\hline $\begin{array}{l}331 \text { - Primary Metal } \\
\text { Manufacturing }\end{array}$ & 1.71 & 23 & 1.51 & 1111 & 0.76 & 3 & 0.36 & 69 \\
\hline
\end{tabular}




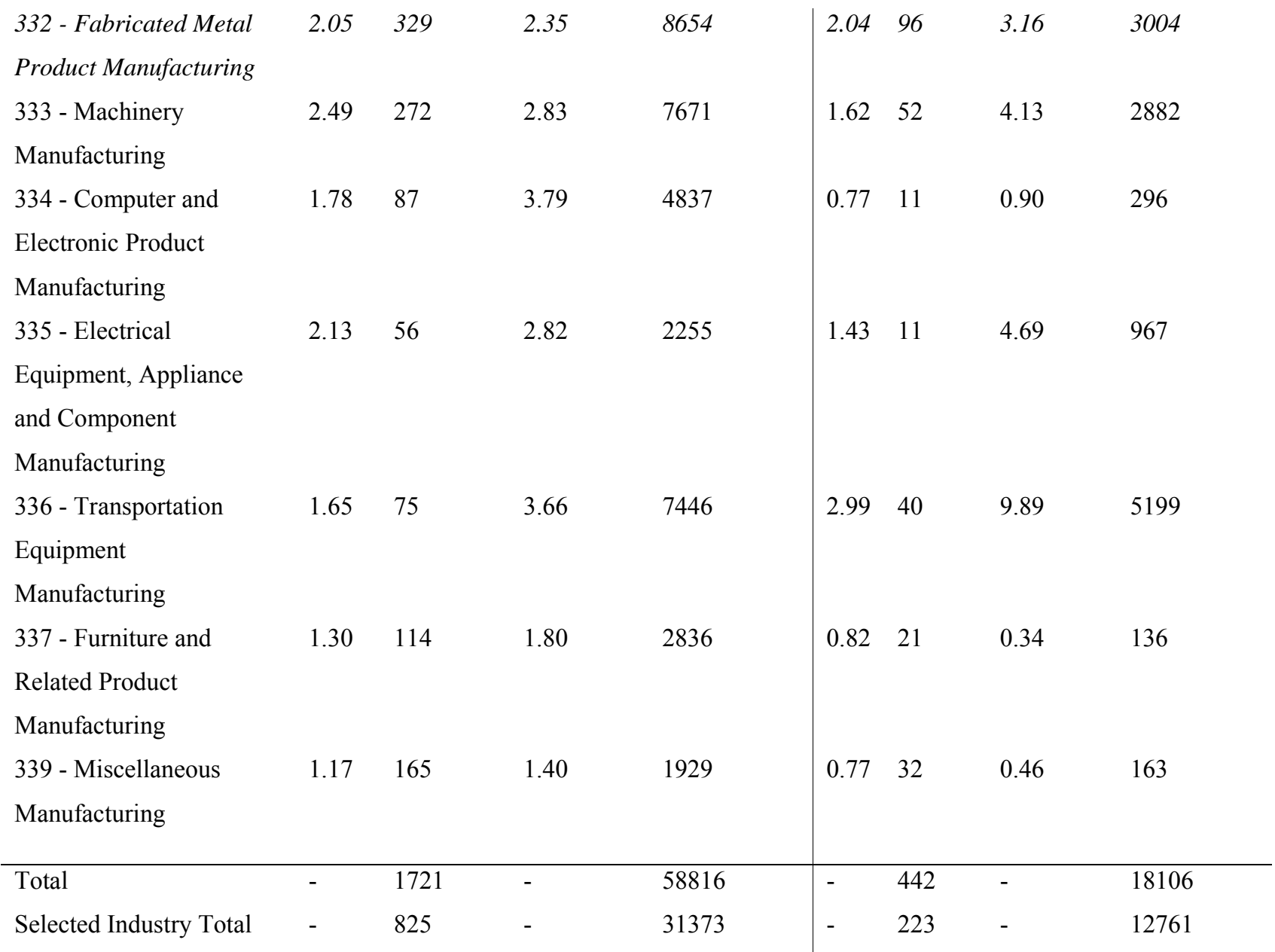

Note: Reference values for the computation of location quotients were the respective Canadian totals. Selected traditional manufacturing sectors are shown in italics. 
Table 2: Number and Share of Interviews in CCT by Location of Firms, 2008-2009 (Source: Survey Results)

\begin{tabular}{lll}
\hline Cities & Firm Population & Firms Interviewed \\
\hline Cambridge & $271(42 \%)$ & $11(28 \%)$ \\
Guelph & $138(21 \%)$ & $15(37 \%)$ \\
Kitchener & $130(20 \%)$ & $7(18 \%)$ \\
Waterloo & $103(16 \%)$ & $7(18 \%)$ \\
\hline Total & $642(99 \%)$ & $40(101 \%)$ \\
\hline
\end{tabular}

Note: $\chi^{2}=7.51(\mathrm{~d} . \mathrm{F} .=3)$ is insignificant at $\alpha=.05$. 
Table 3: Number and Share of Interviews in CTT by Industrial Sector, 2008-2009 (Source: Survey Results)

\begin{tabular}{lll}
$\begin{array}{l}\text { Industrial Sectors by NAICS } \\
\text { Code }\end{array}$ & $\begin{array}{l}\text { Firm } \\
\text { Population }\end{array}$ & Firms Interviewed \\
\hline 326 - Plastics and Rubber & $19(3 \%)$ & $1(2 \%)$
\end{tabular}

Products Manufacturing

332 - Fabricated Metal $\quad 369(60 \%) \quad 26(65 \%)$

Product Manufacturing

333 - Machinery $\quad 139(23 \%) \quad 7(17 \%)$

Manufacturing

335 - Electrical Equipment, $\quad 48(8 \%) \quad 2(5 \%)$

Appliance and Component

Manufacturing

336 - Transportation $\quad 36(6 \%) \quad 4(10 \%)$

Equipment Manufacturing

Total $\quad 611(100 \%) \quad 40(99 \%)$

Note: Not all firms in the data base have NAICS codes assigned to them; therefore the total number of firms is lower than that in Table 1. Some categories are recoded for statistical analysis: $\chi^{2}=1.51($ d.F. $=3)$ is insignificant at $\alpha=.05$. 
Table 4: Number and Share of Interviews in CTT by Firm Size, 2008-2009 (Source: Survey Results)

Number of Firm Population Firms Interviewed

Employees

$244(40 \%) \quad 9(23 \%)$

$11-25 \quad 128(20 \%) \quad 8(20 \%)$

$26-50 \quad 84(14 \%) \quad 6(15 \%)$

$51-75 \quad 36(6 \%) \quad 6(15 \%)$

$76-100 \quad 25(4 \%) \quad 3(8 \%)$

$101+\quad 99(16 \%) \quad 8(20 \%)$

Total $606(100 \%) \quad 40(101 \%)$

Note: Not all firms in the data base have employee numbers assigned to them; therefore the total number of firms is lower than that in Table 1. $\chi^{2}=4.49(\mathrm{~d} . \mathrm{F} .=4)$ is insignificant at $\alpha=.05$. 
Table 5: Structural Data of Firms Interviewed (Source: Survey Results)

\begin{tabular}{|c|c|c|c|c|c|c|c|c|}
\hline $\begin{array}{l}\text { Inter- } \\
\text { view } \\
\text { Code } \\
\end{array}$ & $\begin{array}{l}\text { Year } \\
\text { Estab- } \\
\text { lished }\end{array}$ & $\begin{array}{l}\text { City } \\
\text { (Location) }\end{array}$ & $\begin{array}{l}\text { NAICS } \\
\text { Code }\end{array}$ & Firm Type & $\begin{array}{l}\text { Design } \\
\text { Involve- } \\
\text { ment }\end{array}$ & $\begin{array}{l}\text { Number of } \\
\text { Employees }\end{array}$ & $\begin{array}{l}\text { Revenues } \\
\text { (CAD million, } \\
2008 \text { or } 2009)\end{array}$ & $\begin{array}{l}\text { Revenue } \\
\text { Growth (\%) } \\
\text { Last } 3 \text { Years }\end{array}$ \\
\hline 201 & 1976 & Cambridge & 3329 & Fabrication & None & 25 & 5.0 & 3 \\
\hline 202 & 1994 & Cambridge & 3334 & Fabrication & Limited & 10 & 1.0 & 15 \\
\hline 203 & 1988 & Cambridge & 3329 & Fabrication & Limited & 25 & 4.0 & 20 \\
\hline 204 & 1996 & Kitchener & 3332 & OEM & Control & 36 & 18.0 & N/A \\
\hline 205 & 2003 & Cambridge & 3334 & Assembler & Limited & 24 & N/A & 100 \\
\hline 206 & 1996 & Kitchener & 3322 & Fabrication & Limited & 25 & 3.0 & 0 \\
\hline 207 & 1993 & Cambridge & 3332 & Fabrication & None & 22 & N/A & 15 \\
\hline 208 & 1963 & Cambridge & 3325 & OEM & Control & 85 & N/A & 10 \\
\hline 209 & 1994 & Cambridge & 3325 & Fabrication & Limited & 150 & 15.0 & 0 \\
\hline 210 & 1987 & Guelph & 3329 & Assembler & Limited & 50 & 5.4 & 5 \\
\hline 211 & 1906 & Waterloo & 3352 & OEM & Control & 600 & 200.0 & 12 \\
\hline 212 & 1985 & Kitchener & 3322 & Fabrication & None & 70 & 8.0 & 10 \\
\hline 213 & 1992 & Kitchener & 3363 & OEM & Control & 59 & 35.0 & 5 \\
\hline 214 & 1945 & Guelph & 3329 & OEM & Control & 4 & 0.5 & 0 \\
\hline 215 & 1951 & Guelph & 3329 & OEM & Control & 800 & 200.0 & 4 \\
\hline 216 & 1966 & Waterloo & 3323 & Fabrication & Limited & 45 & 8.0 & 10 \\
\hline 217 & 1976 & Kitchener & 3369 & OEM & Control & 95 & 26.0 & 35 \\
\hline 218 & 1986 & Waterloo & 3327 & Fabrication & None & 20 & N/A & N/A \\
\hline 219 & 1988 & Waterloo & 3334 & Fabrication & Limited & 7 & N/A & N/A \\
\hline 220 & 1957 & Cambridge & 3321 & Fabrication & Limited & 245 & 35.0 & -5 \\
\hline 221 & 1984 & Cambridge & 3327 & Fabrication & None & 22 & 5.0 & 20 \\
\hline 222 & 1960 & Kitchener & 3323 & Fabrication & None & 14 & 3.3 & 100 \\
\hline 223 & 1966 & Guelph & 3361 & OEM & Control & 8087 & $2,300.0$ & 15 \\
\hline 224 & 1974 & Cambridge & 3322 & Fabrication & None & 60 & 24.0 & -45 \\
\hline 225 & 1948 & Kitchener & 3328 & $\begin{array}{l}\text { Coating/ Heat } \\
\text { Treating }\end{array}$ & None & 675 & 75.0 & -40 \\
\hline 226 & 1994 & Waterloo & 3364 & Fabrication & None & 12 & N/A & 15 \\
\hline 227 & 1974 & Waterloo & 3329 & Fabrication & Limited & 60 & 10.0 & 35 \\
\hline 228 & 1944 & Waterloo & 3329 & Fabrication & None & 78 & 9.0 & 12 \\
\hline 229 & 1946 & Guelph & 3323 & Fabrication & None & 65 & 15.0 & 4 \\
\hline 230 & 1989 & Guelph & 3328 & $\begin{array}{l}\text { Coating/ Heat } \\
\text { Treating }\end{array}$ & None & 30 & 5.2 & 5 \\
\hline 231 & 1991 & Cambridge & 3328 & OEM & Control & 350 & 100.0 & 5 \\
\hline 232 & 1955 & Guelph & 3328 & $\begin{array}{l}\text { Coating/ Heat } \\
\text { Treating }\end{array}$ & None & 8 & N/A & N/A \\
\hline
\end{tabular}




\begin{tabular}{|c|c|c|c|c|c|c|c|c|}
\hline 233 & 1917 & Guelph & 3359 & OEM & Control & 501 & 75.0 & 9 \\
\hline 234 & 1990 & Guelph & 3324 & OEM & Control & 4 & N/A & N/A \\
\hline 235 & 1979 & Guelph & 3261 & $\begin{array}{l}\text { Coating/ Heat } \\
\text { Treating }\end{array}$ & None & 2 & N/A & $\mathrm{N} / \mathrm{A}$ \\
\hline 236 & 1990 & Guelph & 3327 & $\begin{array}{l}\text { Coating/ Heat } \\
\text { Treating }\end{array}$ & None & 2 & 0.14 & -66 \\
\hline 237 & 1972 & Guelph & 3331 & OEM & Control & 300 & 300.0 & 20 \\
\hline 238 & 1975 & Guelph & 3332 & Fabrication & Limited & 7 & 1.3 & 3 \\
\hline 239 & 1988 & Guelph & 3327 & Fabrication & Limited & 10 & 1.0 & 0 \\
\hline 240 & 1997 & Guelph & 3363 & Fabrication & Limited & 70 & 24.0 & -50 \\
\hline
\end{tabular}

Notes: OEM = Original Equipment Manufacturer; N/A = not available. 
Table 6: Number of Firms Interviewed in CTT by Role in the Innovation Process, Type of Innovation and Firm Type, 2008-2009 (Source: Survey Results)

Primary Forms of Role of Firms in the Innovation Process

Innovation

by Firm Type

No Role in

Feedback on Full Control of Total

Design

Manufacturing Product/Process

Blueprints Designs

1. Product Innovators $\left(\mathrm{n}_{1}=16\right)$

\begin{tabular}{lllll}
\hline OEMs & 0 & 0 & 12 & 12 \\
Assemblers & 0 & 1 & 0 & 1 \\
Fabrication Shops & 0 & 2 & 0 & 2 \\
Coating/Heat Treating & 1 & 0 & 0 & 1
\end{tabular}

2. Process Innovators $\left(\mathrm{n}_{2}=17\right)$

\begin{tabular}{lllll}
\hline OEMs & 0 & 0 & 0 & 0 \\
Assemblers & 0 & 1 & 0 & 1 \\
Fabrication Shops & 7 & 7 & 0 & 14 \\
Coating/Heat Treating & 2 & 0 & 0 & 2 \\
\hline 3. Non-innovators $\left(\mathrm{n}_{3}=7\right)$ & 0 & 0 & - & 0 \\
\hline OEMs & 0 & 0 & - & 0 \\
Assemblers & 3 & 2 & - & 5 \\
Fabrication Shops & 2 & 0 & - & 2 \\
Coating/Heat Treating & & 13 & 12 & 40 \\
\hline Total & 15 & &
\end{tabular}

Note: OEMs $=$ Original Equipment Manufacturers. 


\section{Endnotes}

${ }^{1}$ CTT was jointly established in the late 1980 s by the cities of Cambridge, Guelph, Kitchener and Waterloo to market the region's technological strengths and reduce intermunicipal competition (Cities of Cambridge, Guelph, Kitchener and Waterloo, 1988; Bathelt and Hecht, 1990). Although Guelph left this initiative later to market its strengths individually, the local economies are still linked to one another, draw from a shared labor market and depend on similar economic conditions, even in traditional manufacturing industries. Therefore, the entire region is referred to here as CTT.

2 An example is the interpretation of Leipzig's economic trajectory as one along a related-variety path (Neffke et al., 2011).

3 Within economic analysis, the term "resiliency" is contested due to the implication that the goal of regions would be to return to economic or industrial equilibrium after an external shock (Christopherson et al., 2010; Hassink, 2010; Pike et al., 2010; Park, 2010). Re-bundling, in contrast, does not pre-suppose a return to previous spatial and industrial configurations, but rather emphasizes and examines the ability of networks of firms and institutions to adjust to new economic realities after periods of rupture.

${ }^{4}$ To conduct research during such an important event, of course, raises serious methodological considerations. In particular, the immediate stress of the crises no doubt had an impact on our respondents. However, this bias is likely to be no greater than that produced by investigating the effects of the crisis years after they have occurred. Studies conducted during a crisis are an important source of knowledge of how firms and regions react to the intense economic pressures brought about. As the most severe effects of the crisis were seemingly overcome when this research was completed, we are confident that the structures and processes identified are not just short-term reactions to the crisis. In fact, our positive evaluation of the ability of firms to minimize crisis effects through innovation, as discussed in the empirical section, is also supported by comments from industry observers. Wilding (2010), for instance, the President of the Toronto Board of Trade, expresses concerns about the economic strength of CTT in relation to Toronto after the economic crisis. In a commentary about a future regional strategy of the Toronto region, she wrote that "city-regions such as London [England], Chicago and even Kitchener/ Waterloo/ Cambridge act as regional zones, snatching new investment and 
jobs away from Toronto ...". The region's economic revival goes also along with a recovery of the Southern Ontario automobile parts industry in 2010 (Van Alphen, 2010). It is clear, however, that future studies will have to be conducted to measure and understand the full effects of the crisis.

5 This was not always obvious when attempting to book interviews with the firms as the telephone numbers were still place. It sometimes took us up to 10 phone calls to find out about the actual state of the firms and receive an answer regarding our interview requests. Our experience included of diverse set of, often unexpected, replies ranging from crying secretaries and an offer to buy a recently closed factory to a phone call with a security guard who was the only person left in the warehouse to make sure the inventory was safe.

${ }^{6}$ Changes to improve the manufacturability of a part were limited to modifications that reduced production costs but did not affect the function of the part in its final assembly.

7 Some firms suggested that this was an intentional strategy. They benefited from the consistency and efficiency of working with a few large customers, but used smaller projects to explore potential opportunities to diversify their customer-base and the industries they serve.

${ }^{8}$ Diversification was also an important strategy in the renewal of the Aberdeen oil complex since the 1990s (Chapman et al., 2004).

9 The trend to diversify into areas such as green machining, wind turbines and solar energy has been an important part of the innovation strategy of regional automobile suppliers, such as Linamar, Magna International and Meikle Automation (Hamilton, 2009).

${ }^{10}$ Even in the middle of Chevrolet's bankruptcy, several smaller firms reported increased sales to Chevrolet because of high consumer demand for the 2010 Camaro.

11 The layoffs were strongest in the automobile production and supplier sector of the region (Van Alphen, 2008; 2009), and particularly hit those operations that were largely or exclusively dependent on Chrysler and GM (Keenan, 2009; GuelphMercury.com, 2009).

12 The firm worked closely with the local material suppliers and allied metal-finishing firms to help them grow large enough to support the firm's operations. This was part of the broader strategy to shift to consumer products and broaden product offerings. 